\title{
Are mutations in K-RAS, BRAF and PIK3CA genes critical for response to adjuvant trastuzumab treatment in patients with HER-2 positive breast cancer?
}

\author{
Anne Marie Bak Jylling ${ }^{1,2^{*}}$, Anders Aamann Rasmussen ${ }^{1,3}$, Erik Hugger Jakobsen ${ }^{3,4}$, René dePont Christensen ${ }^{5}$ and Flemming Brandt \\ Sørensen ${ }^{1,6}$ \\ *Correspondence: anne.marie.bak.jylling@rsyd.dk \\ 'Department of Clinical Pathology, Vejle-Lillebaelt Hospital, Denmark. \\ ${ }^{2}$ Department of Clinical Pathology, Odense University Hospital, Odense, Denmark. \\ ${ }^{3}$ Department of Clinical Genetics, Vejle-Lillebaelt Hospital, Denmark. \\ ${ }^{4}$ Department of Oncology, Vejle-Lillebaelt Hospital, Denmark. \\ ${ }^{5}$ Research Unit of General Practice Odense, Institute of Public Health, University of Southern Denmark, Denmark. \\ ${ }^{6}$ Institute of Regional Health Research, University of Southern Denmark, Denmark.
}

\begin{abstract}
Background: HER-2 is a prognostic and predictive factor in patients suffering from breast cancer. Since 2006 we have tested routinely the HER-2 status in patients with primary breast cancer at Vejle Hospital, Denmark, to evaluate the indication for treatment with trastuzumab in the adjuvant setting. Although this treatment improves the prognosis in patients with HER-2 positive breast tumours, it seems that some patients do not respond to the treatment. Various molecular genetic pathways may be responsible for such resistance to trastuzumab therapy, e.g., mutations in the PIK3CA-gene. Mutation in the K-RAS-gene has critical impact in selecting patients with colorectal cancer for targeted anti-EGFR treatment, but has only been sparsely investigated in patients with breast cancer. It is the purpose of the present study to evaluate, whether such mutations may influence the response to trastuzumab treatment.

Methods: Paraffin-embedded breast cancer tissue from 69 women, treated according to protocol with trastuzumab in an adjuvant setting from 2006 through 2008, and 16 women, also treated with trastuzumab in an individualized setting from 2003 through 2005 were included, and analyzed for somatic mutation of the K-RAS, BRAF and PIK3CA genes in their breast tumours. The results were compared with clinical behaviour, receptor status, tumour grade, size, and lymph node status.

Results: In the 2006-08 material, PIK3CA mutations were detected in $26 \%$ of the tumours, whereas no BRAF or K-RAS mutations were found. In the 2003-05 material we documented PIK3CA mutations in 31\%, BRAF in 6\% (1 tumour), and K-RAS in none of the tumours. All patients experiencing relapse $(\mathrm{N}=17)$ had metastatic disease. No statistically significant associations were detected between PIK3CA mutation status and the clinico-pathological variables or the clinical outcome.

Conclusions: $K-R A S$ and BRAF mutations are rare events in breast cancer, whereas PIK3CA-mutation is encountered in more than one fourth of HER-2 positive breast cancers, but seems without predictive impact regarding treatment response to trastuzumab in the investigated series of patients.
\end{abstract}

Keywords: Breast cancer, $B R A F$, HER-2, K-RAS, PIK3CA, treatment failure

\section{Introduction}

Breast cancer is the most frequent cancer type among Danish women with almost 5000 new cases each year and 1200 deaths [1]. In the last decades the prognosis has, however, improved. Especially, this has been related to the introduction of Human Epidermal Growth Factor Receptor-2 (HER-2) testing, for evaluating the indication for Herceptin (trastuzumab) treatment, which has improved the course of disease for patients suffering from breast cancer [2-5].

HER-2 is a routinely tested biomarker together with estrogen receptor (ER) and in some settings Topoisomerase lla (TOP2A). In the population of patients with breast cancer HER-2 is overexpressed or amplified in approximately $12-15 \%$ of the cases [6]. As a prognostic marker, HER-2 over-expression/amplification indicates a worse prognosis, but it also serves as a predictive marker, indicating response to the targeted therapy with the humanized, monoclonal antibody trastuzumab [4]. Treatment with trastuzumab improves the prognosis for patients with HER-2 positive tumours [2-5], but unfortunately, some of these patients do not respond to the treatment $[7,8]$, and hence do not obtain a significant improvement in disease control. The reasons for such treatment failure may be due to trastuzumab resistance, which may be caused by alterations in one or more of the several molecular pathways regulating the functional effects of HER-2.

Attempts to classify breast cancers by gene expression profiling have emerged [9-12]. This extensive research has identified a variety of genes, in which oncogenic driver mutations may develop, but at the same time disclosed a substantial genetic diversity associated with the development 
and progression of breast cancer [13]. In this context, the genetic alterations in high risk, so-called triple-negative breast cancer have been investigated in detail. Somatic mutation in the catalytic subunit of the phosphatidylinositol 3-kinase (PIK3CA) in the PIK3 pathway $[\mathbf{1 4 , 1 5 - 1 7 ]}$ is well-documented in such tumours. The occurrence of mutations in the $K-R A S$ gene $[14,17-19]$ in the EGFR stimulation pathway, and the $B R A F$ gene $[17,19]$ in the MAPK/ERK signalling pathway, are more controversial in this context. Being in control of cellular proliferation and differentiation, these genes may be of crucial importance. Thus, a functional variant of the KRAS oncogene has been suggested as a genetic marker for the development of triple-negative breast cancer [20], and a specific K-RAS mutation has been ascribed prognostic value in patients receiving neoadjuvant chemotherapy for their breast tumours [21].

The molecular fingerprint of a breast carcinoma seems pivotal for our understanding of tumour behaviour and the clinical response to various treatments. Especially, this knowledge may be rewarding in the clinical management of patients with aggressive breast cancers, like triple-negative tumours. The molecular genetic approach may, however, also be advisable in patients with HER-2 positive breast tumours, in that the molecular constitution in such tumours may be of predictive value regarding the efficacy of targeted therapy with trastuzumab. The PI3K signalling pathway has been suggested as one main actor in this regard $[22,23]$ being in control of features like apoptosis and proliferation. Moreover, mutation in the PIK3CA gene has been detected in $20-40 \%$ of primary breast cancers $[16,24]$. Accordingly, PIK3CA mutation may be an oncogenic candidate for altering the effectiveness of trastuzumab by eliminating the HER-2 inhibition.

The EGFR stimulation pathway involves the K-RAS and $B R A F$ genes and may also be of interest, when addressing treatment failure of trastuzumab, in that mutations in these genes are important when offering targeted treatment to patients with other kinds of cancers, e.g., colorectal cancer and malignant melanoma [25].

The impact of these genes in the development and progression of breast cancer has been investigated by in vitro studies $[14]$ and in a clinical setting $[15,16,18,19,21,23,26]$. Most of these studies have had preference for studying patients with triple-negative breast tumours, but whether mutations in PIK3CA, KRAS and/or BRAF may influence the efficiency of trastuzumab therapy in patients with HER-2 positive breast cancer awaits further elucidation. The purpose of the present investigation was to evaluate the frequencies of mutations in the PIK3CA, KRAS and BRAF genes in HER-2 positive breast cancer, and whether such mutations may be critical regarding treatment response to trastuzumab.

\section{Materials and methods Patients}

The files of the Departments of Surgery, Oncology and Clinical
Pathology, Vejle Hospital, Lillebaelt Hospital, Denmark, were searched for patients, who had undergone intended curative surgical treatment for breast cancer and fulfilling the following inclusion criteria: trastuzumab therapy intended for one year (17 series, 3 weeks apart), administered in an adjuvant setting together with chemotherapy, and in case of lumpectomy, radiation therapy, according to recommendations by Danish Breast Cancer Cooperative Group (DBCG). Tissue should be available for research. Two periods were screened for such patients: From January 2006 through December 2008, 110 consecutive patients were retrieved. These patients had been treated according to the DBCG protocols no. DBCG05H and DBCG07. In the period from 2003 through 2005, another 20 patients were recruited. These patients had basically been treated according to the HERA protocol, and were typically defined by young age and/or at high risk of recurrence, or were selected for adjuvant treatment based on a clinical evaluation. All patients were women.

Reasons for exclusion were: metastatic/disseminated disease at the time of diagnosis $(\mathrm{N}=14)$, recurrent disease $(\mathrm{N}=7)$, bilateral breast cancer with different HER2 status $(\mathrm{N}=3)$, no tissue available or too small cellular tumour fraction $(<75 \%, N=19)$, and in 2 cases the molecular analyses were not evaluable.

Tumour size, malignancy grade, estrogen receptor status, and lymph node status were registered. The clinical courses of the patients were retrieved from the clinical records obtained with regular intervals, when the patients were seen in the Oncologic Outward Clinic, Vejle Hospital, or by retrieval of data from the clinical files of the local hospital taking care of the patients.

The project was approved by the local Committee for Health Research Ethics of Southern Denmark (ID.no. S-20080119) and the Danish Data Protection Agency (ID.no. 2008-41-2691).

\section{Histopathology}

Tissue sections ( $4 \mu \mathrm{m}$ thick) were cut from the routinely processed, formalin fixed and paraffin embedded (FFPE) tissue blocks (trimmed to optimize content of invasive tumour) from the surgical specimen, except in the cases of women receiving neoadjuvant therapy, where only the pre-operative, diagnostic biopsies were available. The tumours were graded according to the modified Bloom-Richardson classification, recommended by DBCG [27], except 2 cases of medullary and one case of metaplastic carcinoma. Apart from haematoxylin and eosin stains, the tissue sections had all, at the time for primary diagnosis, been tested for HER-2 expression, according to the national guidelines [28], and accepted positive with a result of the Herceptest ${ }^{\mathrm{TM}}$ (DAKO, Glostrup, Denmark) of 3+, indicating over-expression ( $\mathrm{N}=73)$. In cases with Herceptest ${ }^{\mathrm{TM}}$ score of $2+$ $(\mathrm{N}=12)$, in situ hybridisation (ISH) had been carried out (HER-2 FISH pharmDxt Kit ${ }^{\mathrm{TM}}$, Code K5331, DAKO, Glostrup, Denmark), according to the manufacturer's protocol, and a score of $\geq 2$ indicated HER-2 amplification. Finally, immunohistochemical 
staining for estrogen receptor (ER) had been performed (clone SP1, LabVision, USA), and, in the period 2003 through 2008, registered as positive, when more than $10 \%$ of the tumour cell nuclei were positive [29].

\section{Molecular pathology \\ Tissue specimens}

Three, $15 \mu \mathrm{m}$ thick tissue sections were cut in serial, using RNAse free environment with extensive cleaning of the microtome and mounting of a new knife between the processing of each case, and using the same tissue blocks as used for immunohistochemical staining at the time of diagnosis. In addition, one, $4 \mu \mathrm{m}$ section was cut from the top and from the bottom of each stack of serial sections, respectively, to check the fraction of invasive tumour in the sections to be used for molecular studies. The fraction of invasive tumour was semi-quantitatively estimated, and should constitute $\geq 75 \%$ of the cellular population in the tissue sections to be included in the study.

\section{DNA purification and PIK3CA, BRAF, and K-RAS mutation detection}

DNA extraction from the FFPE tissue sections was carried out, using QIAamp DNA Mini Kit (QIAGEN), according to the manufacturer's instruction.

PIK3CA (RefSeq gene NG_012113.1; RefSeq mRNA NM_006218.2) exon 9 and 20 were amplified in a duplex PCR, using the primers PI3K 9F, 5'-AAA TTT ATT GAA AAT GTA TTT GCT TTT TC; PI3K 9R, 5'-TCC ATT TTA GCA CTT ACC TGT GA; PI3K 20F, 5'-ATG ATG CTT GGC TCT GGA AT; and PI3K 20R, GGT CTT TGC CTG CTG AGA GT. Approximately 20ng of DNA

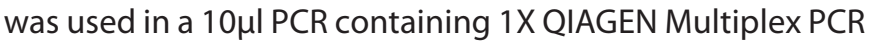
Master Mix (QIAGEN) and $0.2 \mu \mathrm{M}$ of each primer. Thermocycling steps were as follows: $95^{\circ} \mathrm{C}$ for $15 \mathrm{~min} ; 45$ cycles of $94^{\circ} \mathrm{C}$ for $30 \mathrm{sec}, 60^{\circ} \mathrm{C}$ for $90 \mathrm{sec}$ and $72^{\circ} \mathrm{C}$ for $90 \mathrm{sec}$; followed by $72^{\circ} \mathrm{C}$ for $10 \mathrm{~min}$. After cycling, the presence of appropriate PCR products was confirmed by agarose gel electrophoresis. PCR products were cleaned by exo-SAP-IT (GE Healthcare) treatment, as described by manufacturer. PCR products were sequenced in both directions with nested primers (PI3K 9Fseq, 5)-CTG TGA ATC CAG AGG GGA AA; PI3K 9Rseq_ext, 5-TTT ATT TAT TTA TTT ATT TAT TTA TTT ATT TAT CCA TTT TAG CAC TTA CCT GTG A; PI3K 20F, 5'-ATG ATG CTT GGC TCT GGA AT; PI3K 20Rseq, GGA ATC CAG AGT GAG CTT TCA), using BigDye Terminator v1.1 Cycle Sequencing Kit (Life Technologies) and BigDye Xterminator (Life Technologies) followed by capillary electrophoresis on an ABI 3130 Genetic Analyzer (Life Technologies). Mutations were identified by visual inspection of DNA sequence electropherograms generated by Sequence Analysis Software v5.2 (Life Technologies).

BRAF (RefSeq mRNA RefSeq NM_004333.4), c.1799T>A, (p.V600E) mutation status was analysed by allele-specific real-time PCR using ABI 7900 HT Sequence Detection System (Life Technologies), essentially as previously described
[30]. In brief, the analysis consisted of two different PCRs: one control reaction, called BRAF wt, to verify presence of sufficient amplifiable DNA and one reaction, called $B R A F$ c. $1799 \mathrm{~T}>\mathrm{A}$, to probe for the mutation. Both reactions were carried out in duplicates. Primers, probes and blocker used in the two reactions were BRAF F, 5'-AAA TAG GTG ATT TTG GTC TAG CTA CAG (modified from [30]); BRAF F Mut, 5'-AGG TGA TTT TGG TCT AGC TAC AGA [30]; BRAF R-18.5; 5'-CCA CAA AAT GGA TCC AGA CAA CTG; BRAF P-21.5, FAM-CAA ACT GAT GGG ACC CAC TCC ATC G-BHQ-1; BRAF wt blocker $A^{*}+G+C+T+A+C+A+G+T+G+A / 3$ Phos/ (modified from [31]); *phosphorothioate bond, +: LNA, 3Phos: 3' Phosphorylation). The $25 \mu$ l BRAF wt reaction contained 1X Universal PCR Master Mix (Life Technologies), $2 \mu$ purified DNA, BRAF F (900 nM), BRAF R-18.5 (900 nM), BRAF P-21.5 (300 nM). The $25 \mu \mathrm{l}$ BRAF c. $1799 \mathrm{~T}>\mathrm{A}$ reaction contained $1 \mathrm{X}$ Universal PCR Master Mix (Life Technologies), $2 \mu$ l purified DNA, BRAF F Mut (900 nM), BRAF R-18.5 (900 nM), BRAF P-21.5 (300 nM), and BRAF wt blocker $(3 \mu \mathrm{M})$. Cycling steps were as follows: $50^{\circ} \mathrm{C}$ for $2 \mathrm{~min}$; $95^{\circ} \mathrm{C}$ for $10 \mathrm{~min} ; 50$ cycles of $95^{\circ} \mathrm{C}$ for $15 \mathrm{sec}, 63^{\circ} \mathrm{C}$ for $1 \mathrm{~min}$.

KRAS (RefSeq NM_033360.2) mutation status was assessed using the KRAS Mutation Detection Kit (Cat. GP05-C2, TrimGen Corporation) according to the manufacturers recommendations with minor modifications: QIAGEN Multiplex PCR Master Mix (QIAGEN) was used for the PCR reaction; $\mathrm{Hi}$-Di formamide and GS500 ROX size standard (Life Tecnologies) were used for capillary electrophoresis. This assay detects and differentiates between 12 mutations: c.34G >A, (p.G12S); c.34G >C, (p.G12A); c.34G > T, (p.G12C); c.35G >A, (p.G12D); c.35G >C, (p.G12A); c.35G >T, (p.G12V); c.37G >A, (p.G13S); c.37G >C, (p.G13A); c.37G >T, (p.G13V); c.38G>A, (p.G13D); c.38G >C, (p.G13A); and c.38G $>$ T, (p.G13V).

\section{Statistical analysis}

For each series of patients the clinico-pathological characteristics were tabulated according to the inclusion period and all together. Using chi-square or Fischer exact tests the associations between mutation status and these variables were tested. For each of the two patient cohorts and all together, the recurrence-free survival (RFS) was estimated by the Kaplan-Meier method, and reported by series of the inclusion periods and by mutation hazard. The level of significance for tests was $p<0.05$, and all statistical analysis were carried out using STATA 11.2 (Stata Corp. College Station, TX).

\section{Results}

Clinico-pathological parameters of the two patient cohorts are shown in Table 1. There were no K-RAS mutations among the evaluated tumours and only one patient with $B R A F$ mutated tumour was detected in the 2003-05 cohort. The frequency of PIK3CA mutations in the 2006-08 and 2003-05 series of patients was $26 \%$ and $31 \%$, with $4 \%$ and $6 \%$ in exon 9 and $22 \%$ and $25 \%$ in exon 20 , respectively. None of the investigated 
tumours showed mutation in both exons.

All patients experiencing relapse had metastatic disease (Table 1). The RFS was quite different in the two groups of patients (Figure 1). No statistically significant associations were, however, detected between the PIK3CA mutation status and the clinico-pathological variables or the clinical outcome (Table 2 ).

\section{Discussion}

Targeted therapy is revolutionizing the contemporary basis for oncologic treatment. To find the right therapy for the right patient at the right time is clinically challenging, and has stimulated the search for molecular, predictive and prognostic markers to provide information as to whether or not a patient is likely to benefit from a specific onco-medical therapy. Moreover, such treatments have put a large burden on the health economy, and may be associated with serious side effects. Thus, the need for molecular, predictive markers is mandatory to increase drug efficiency and decrease toxicity [32].

This also applies to patients with breast cancer. Molecular genetic alterations have been documented in a number of studies, using advanced gene-profiling techniques [9-12], and the translational process into a clinical context has especially been applied to high risk patient populations, like the triplenegative breast cancer cohort [15-20]. Such studies often are based on a high-tech analytic infrastructure, stigmatising the molecular genetic approach as both rather complex and incomprehensive. However, insight into the diverse molecular genetic alteration occurring in the cancer cell genome is mandatory for the development and clinical applicability of new targeted onco-medical therapies. Moreover, the efficacy of already implemented targeted anti-cancer therapies, like e.g., trastuzumab, should also be addressed in this context, to evaluate the cost-benefit aspects of these often rather toxic and expensive treatments. Indeed, such studies may provide a quality control of the targeted, therapeutic approach, and may even improve our clinical ability to implement the right treatment for the right patient at the right time. This prompted us to carry out the present study, evaluating whether the molecular constitution in HER-2 positive tumours may be of predictive value regarding the efficacy of targeted therapy with trastuzumab.

The clinical administration of trastuzumab started out more

Table 1. Patient and tumor characteristics, classified according to PIK3CA mutational status.

\begin{tabular}{|c|c|c|c|c|c|c|}
\hline \multirow[t]{2}{*}{ Inclusion year } & \multicolumn{2}{|c|}{$2006-08(\mathrm{~N}=69)$} & \multicolumn{2}{|c|}{ 2003-05 $(\mathrm{N}=16)$} & \multicolumn{2}{|c|}{ Total $(\mathrm{N}=85)$} \\
\hline & Mutation & Wild type & Mutation & Wild type & Mutation & Wild type \\
\hline Number of patients, $(\%$ of $N)$ & $18(26)$ & $51(74)$ & $5(31)$ & $11(69)$ & $23(27)$ & $62(73)$ \\
\hline \multicolumn{7}{|l|}{ Tumor size } \\
\hline $0-20 \mathrm{~mm}$ & $6(33)$ & $24(47)$ & $0(0)$ & $4(36)$ & $6(26)$ & $28(45)$ \\
\hline $21-50 \mathrm{~mm}$ & $11(61)$ & $22(43)$ & $3(60)$ & $5(45)$ & $14(61)$ & $27(44)$ \\
\hline$>50 \mathrm{~mm}$ & $1(6)$ & $5(10)$ & $2(40)$ & $2(18)$ & $3(13)$ & $7(11)$ \\
\hline Malignancy grade* & & $(\mathrm{N}=49)$ & & $(\mathrm{N}=10)$ & & $(\mathrm{N}=59)$ \\
\hline Grade I & $0(0)$ & $4(8)$ & $0(0)$ & $1(10)$ & $0(0)$ & $5(8)$ \\
\hline Grade II & $6(33)$ & $17(35)$ & $1(20)$ & $6(60)$ & $7(30)$ & $23(39)$ \\
\hline Grade III & $12(67)$ & $28(57)$ & $4(80)$ & $3(30)$ & $16(70)$ & $31(53)$ \\
\hline \multicolumn{7}{|l|}{ ER status } \\
\hline Positive & $9(50)$ & $30(59)$ & $3(60)$ & $3(27)$ & $11(48)$ & $29(47)$ \\
\hline Negative & $9(50)$ & $21(41)$ & $2(40)$ & $8(73)$ & $12(52)$ & $33(53)$ \\
\hline \multicolumn{7}{|l|}{ Lymph node status } \\
\hline Positive & $8(44)$ & $28(55)$ & $4(80)$ & $7(64)$ & $12(52)$ & $35(56)$ \\
\hline Negative & $10(56)$ & $23(45)$ & $1(20)$ & $4(40)$ & $11(48)$ & $27(44)$ \\
\hline \multicolumn{7}{|l|}{ HER-2 treatment } \\
\hline Trastuzumab adjuvant & $13(72)$ & $40(78)$ & $4(80)$ & $11(100)$ & $15(65)$ & $43(69)$ \\
\hline Trastuzumab neo-adjuvant + adjuvant & $5(28)$ & $11(22)$ & $1(20)$ & $0(0)$ & $8(35)$ & $19(31)$ \\
\hline \multicolumn{7}{|l|}{ Clinical Course } \\
\hline No signs of relapse & $18(100)$ & $44(86)$ & $0(0)$ & $6(55)$ & $18(78)$ & $50(81)$ \\
\hline Locoregional disease & $0(0)$ & $0(0)$ & $0(0)$ & $0(0)$ & $0(0)$ & $0(0)$ \\
\hline Metastatic disease & $0(0)$ & $7(14)$ & $5(100)$ & $5(45)$ & $5(22)$ & $12(19)$ \\
\hline
\end{tabular}

*some tumor types not graded. 


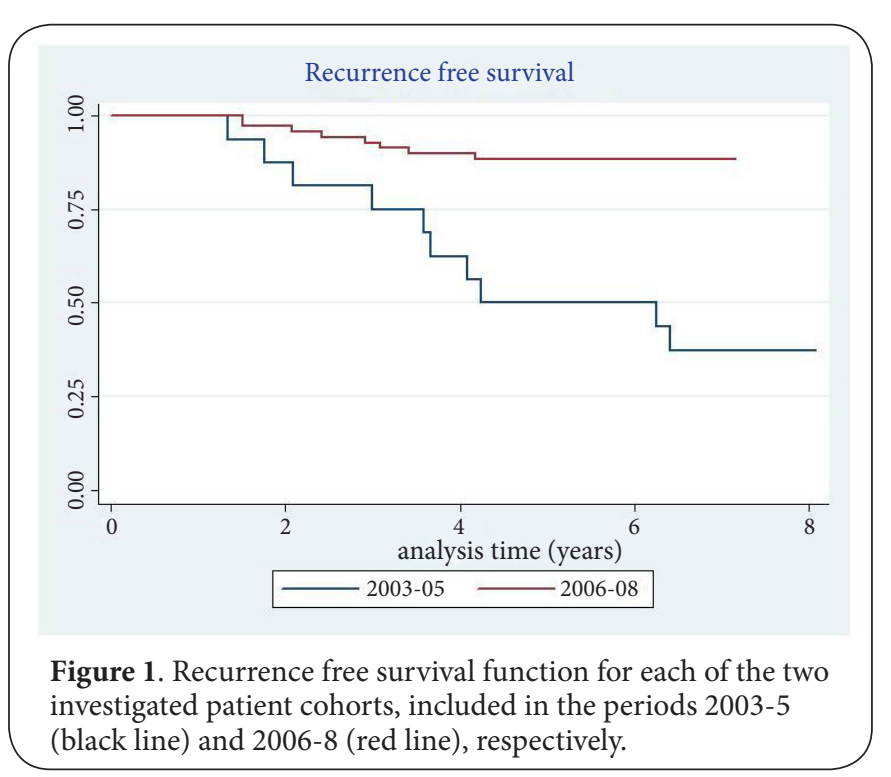

Table 2. Statistical analysis regarding recurrence-free survival (RFS) with associated confidence intervals (CI).

\begin{tabular}{lllll}
\hline Inclusion year & \multicolumn{2}{c}{$2006-\mathbf{0 8}$} & \multicolumn{2}{c}{ 2003-05 } \\
\hline & $\begin{array}{l}\mathbf{5} \text { yr RFS } \\
\text { fraction }\end{array}$ & $\mathbf{9 5 \%}$ CI & 5 yr RFS fraction & $\mathbf{9 5 \%}$ CI \\
\hline Mutation & 1.00 & $\mathrm{NA}^{*}$ & $\mathrm{NA}^{* *}$ & $\mathrm{NA}^{* *}$ \\
Wild type & 0.84 & $0.71-0.92$ & 0.73 & $0.37-0.90$ \\
All & 0.88 & $0.78-0.94$ & 0.50 & $0.25-0.71$ \\
\hline
\end{tabular}

$\left(\mathrm{NA}^{*}=\right.$ Not applicable, $\mathrm{NA}^{* *}=$ There are no observations in this subgroup past 4.25 years, thus 5 yr RFS could not be estimated. At 4 years the numbers were $\mathrm{RFS}=0.20$ with $95 \% \mathrm{CI}=[0.01-0.58])$.

than a decade ago, and proved effective in patients with metastatic breast cancer [2]. Later on, trastuzumab has been offered to patients with breast cancer in an adjuvant setting $[3,4]$. There is no doubt that a large group of patients with HER2 positive breast cancer benefits from trastuzumab therapy, but treatment failure occurs both in the advanced, metastatic setting $[2,33,34]$ and in patients receiving trastuzumab as adjuvant therapy for their non-metastatic, early breast cancer $[35,36]$.

The mechanisms underlying resistance to trastuzumab treatment, either primary or acquired, have been linked to various somatic mutations taking place in the genetically deranged, malignant neoplasms. Among these molecular events, mutation in the K-RAS, BRAF and PIK3CA genes have been addressed, in that these genes play key roles in the cellular homeostasis, including participation in the regulation of cellular growth, proliferation, survival, apoptosis and differentiation. Especially, alterations in the Phosphatidylinositol-3-Kinase (PIK3)-Protein kinase B (Akt) signalling pathway may interfere with HER-2 inhibition [37-40].

None of the tumours investigated harboured K-RAS mutation.
It may be that $K$-RAS mutations, as opposed to colorectal cancer [32], do not play a role regarding the molecular genetic derangement occurring in HER-2 positive breast cancers. The same may apply to BRAF mutations, as only one patient showed this mutation in her tumour. These findings corroborate the results from an earlier in vitro investigation [14], and investigations of triple-negative tumours, stating KRAS and $B R A F$ mutations as rather rare events in breast cancer $[19,26]$. These latter studies were based on sample sizes between 35 and 105 patients, and the findings have rather recently been reproduced in of series of 107 patients with triple-negative breast tumours [17]. One study, from 2013 with a sample size of 116 breast cancer patients, was identified, reporting a KRAS mutation frequency of $8 \%$ [21].

In contrast, we detected mutations in PIK3CA in about one quarter to one third of the patients in the two patient cohorts, respectively. These data agrees with the findings in earlier studies. Somatic PIK3CA mutations have thus been documented with an overall frequency of about $25 \%[22,24]$. Wide variations in the frequency of PIK3CA mutations have, however, been reported [41-43], and mutation rates of $40 \%$ have been disclosed [44], and even as high as $46 \%$ in lobular breast carcinomas [45]. The patient cohort treated in the period 2003-5 had a higher incidence of PIK3CA mutation, which may reflect the selective, clinical basis on which these patients were recruited. However, this series of patients is rather small, and may not be generally comparable to larger studies. The frequency of PIK3CA mutation in the larger patient cohort, treated in the period 2006-8, corresponds to the general mutation rate reported in the literature.

We were unable to detect any significant association between the occurrence of PIK3CA mutation and the clinico-pathological variables investigated, which is in agreement with a recent study of 240 patients with HER-2 positive, early stage breast cancer receiving adjuvant trastuzumab treatment [24]. Moreover, there seems to exist quite some discrepancies in the literature regarding the possible association of PIK3CA mutation as a biomarker to well known pathological parameters of prognostic significance in patients with breast cancer. Thus, PIK3CA mutations have been reported correlated with both lymph node negativity [41] and positivity [46] in breast cancer patients, and moreover, significant associations have been documented with both larger [47] and smaller [48] breast tumour diameters. The present study did not disclose any association between PIK3CA mutation and patient outcome, measured as RFS, although 17 patients out of 85 experienced metastatic recurrence of their breast cancer. The rather few events prevented investigation into possible impact on overall survival. For the same reason we could not reliably evaluate wheter there might be a different prognostic impact between exon 9 and exon 20 in PIK3CA. The overall relapse rate was about $20 \%$, irrespective being tumours with wild type or mutated PIK3CA, and comparable to another recent study [24]. The 2003-5 patient cohort showed a higher fraction of recurring tumours, 
which may reflect the individualized, clinical selection of these high risk patient for adjuvant trastuzumab treatment. Our patient series may be too small to detect any impact of PIK3CA mutation with regard to prognosis. There is, however, conflicting results in the literature on the possible predictive and prognostic value of PIK3CA mutation, which may question the validity of this molecular alteration, when being proposed as a biomarker in patients with HER-2 positive breast cancer. Some studies have shown adverse prognostic impact of PIK3CA mutations [24,49-51]. In contrast, other studies have suggested PIK3CA mutation as a favourable prognostic factor $[42,52]$, including one investigation based on a rather large series of patients $(\mathrm{N}=590)$ [41]. Furthermore, one study has reported PIK3CA mutation, involving exon 20, associated with a favourable prognosis [42], whereas another investigation concludes the opposite [51].

In the setting of HER-2 positive cancer, one might assume that uncontrolled downstream pathway activation would impair the efficacy of trastuzumab. This may suggest other members of the PI3K pathway to be important in relation to failure of HER-2 inhibition. In silico and preclinical observations also point in this direction [53], in that PI3K pathway activation, defined as Phosphatase and Tensin Homolog (PTEN) loss and/ or PIK3CA mutation, seems associated with a poor response to trastuzumab. Indeed, data from more studies have suggested a combined approach, where PIK3CA mutation and/or PTEN loss may improve predictive power as to the efficacy of tratuzumab

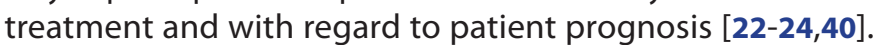
Thus, a more holistic view on the molecular alterations, using an integrated genomic and proteomic approach [54], may in the future improve our ability to predict treatment outcome and prognosis, and, moreover, design multi-axial, targeted treatment regimens that hopefully will improve patient outcome.

In the approach for solving the pathogenesis of trastuzumab treatment failure in patients with HER-2 positive breast cancer, one should, however, not only look for abnormal molecular events taking place in the various pathways of relevance. The bio-availability and-affinity of trastuzumab to the cancer cells are of outmost importance. Tumour-related issues like angiogenesis, high intra-tumoural pressure, stroma, inflammatory response and other variables inherent to the tumour cell microenvironment are crucial. This may also influence our approach to diagnose HER-2 over-expression and thus predict the outcome of trastuzumab treatment. Some attempts have already been carried out in this regard, showing biotinylated Herceptin ${ }^{\circ}$ being superior to Herceptest ${ }^{\mathrm{TM}}$ in predicting the clinical response to trastuzumab $[\mathbf{5 5}, \mathbf{5 6}]$.

In conclusion, the present study documents an approximate $30 \%$ frequency of PIK3CA mutation in HER-2 positive tumours from patients with breast cancer, treated in an adjuvant setting, whereas $K-R A S$ and BRAF mutations were non-existing or rare, respectively. The mutational status was, however, not related to any clinico-pathological variables or recurrence- free survival. The size of the studied cohort is limited, but the results obtained from the descriptive study, corroborates the controversies stated in the literature regarding the clinical impact of PIK3CA mutation in patients with breast cancer. Future studies should focus on an integrated approach, taking into account more members of the PI3K pathway, focusing on their interplay, in the attempt to elucidate trastuzumab treatment failure in patients with HER-2 positive breast cancer.

\section{Competing interests}

The authors declare that they have no competing interests.

Authors' contributions

\begin{tabular}{|l|c|c|c|c|c|}
\hline Authors' contributions & AMBJ & AAR & EHG & RDC & FBS \\
\hline Research concept and design & $\checkmark$ & $\checkmark$ & -- & -- & $\checkmark$ \\
\hline Collection and/or assembly of data & $\checkmark$ & $\checkmark$ & $\checkmark$ & -- & $\checkmark$ \\
\hline Data analysis and interpretation & $\checkmark$ & $\checkmark$ & -- & -- & $\checkmark$ \\
\hline Writing the article & $\checkmark$ & -- & -- & -- & $\checkmark$ \\
\hline Critical revision of the article & $\checkmark$ & -- & -- & $\checkmark$ & $\checkmark$ \\
\hline Final approval of article & $\checkmark$ & $\checkmark$ & $\checkmark$ & $\checkmark$ & $\checkmark$ \\
\hline Statistical analysis & -- & -- & -- & $\checkmark$ & -- \\
\hline
\end{tabular}

\section{Acknowledgement}

We are grateful for the excellent technical assistance provided by Kaja Skovgård Jensen, Birgit Roed Sørensen and Martin Nielsen, and the eminent help with providing clinical data offered by Gitte Eiberg Møller and her team. This study was supported by grants from Mads Clausen's Foundation, The A. P. Møller Foundation for the Advancement of Medical Science, Eva \& Henry Frænkel's Foundation, Max \& Anna Friedmann's Foundation, The Family Hede Nielsen's Foundation, The Harboe Foundation, and Th. Maigaard's Successor Mrs. Lily Benthine Lund's Foundation of June 1 st 1978.

\section{Publication history}

EIC: G. J. Peters, VU University Medical Center, Netherlands. Received: 04-Feb-2014 Final Revised: 12-Mar-2014

Accepted: 01-Apr-2014 Published: 14-Apr-2014

\section{References}

1. NORDCAN: Cancerstatistics. Denmark, Breast (2007-11). | Website

2. Slamon DJ, Leyland-Jones B, Shak S, Fuchs H, Paton V, Bajamonde A Fleming T, Eiermann W, Wolter J, Pegram M, Baselga J and Norton L. Use of chemotherapy plus a monoclonal antibody against HER2 for metastatic breast cancer that overexpresses HER2. N Engl J Med. 2001; 344:783-92. | Article | PubMed

3. Piccart-Gebhart MJ, Procter M, Leyland-Jones B, Goldhirsch A, Untch M, Smith I, Gianni L, Baselga J, Bell R and Jackisch C et al. Trastuzumab after adjuvant chemotherapy in HER2-positive breast cancer. $N$ Engl J Med. 2005; 353:1659-72. | Article | PubMed

4. Baselga J, Perez EA, Pienkowski T and Bell R. Adjuvant trastuzumab: a milestone in the treatment of HER-2-positive early breast cancer. Oncologist. 2006; 11 Suppl 1:4-12. | Article I PubMed

5. Perez EA, Romond EH, Suman VJ, Jeong JH, Davidson NE, Geyer CE, Jr., Martino S, Mamounas EP, Kaufman PA and Wolmark N. Four-year follow-up of trastuzumab plus adjuvant chemotherapy for operable human epidermal growth factor receptor 2-positive breast cancer: joint analysis of data from NCCTG N9831 and NSABP B-31. J Clin Oncol. 2011; 29:3366-73. | Article | PubMed Abstract | PubMed Full Text

6. Koninki K, Tanner M, Auvinen A and Isola J. HER-2 positive breast cancer: 
decreasing proportion but stable incidence in Finnish population from 1982 to 2005. Breast Cancer Res. 2009; 11:R37. | Article | PubMed Abstract | PubMed Full Text

7. Jones $K L$ and Buzdar AU. Evolving novel anti-HER2 strategies. Lancet Oncol. 2009; 10:1179-87. | Article | PubMed

8. Dean-Colomb W and Esteva FJ. Her2-positive breast cancer: herceptin and beyond. Eur J Cancer. 2008; 44:2806-12. | Article | PubMed

9. Perou $C M$, Sorlie $T$, Eisen $M B$, van de Rijn $M$, Jeffrey $S S$, Rees $C A$, Pollack $J R$, Ross DT, Johnsen H, Akslen LA, Fluge O, Pergamenschikov A, Williams C, Zhu SX, Lonning PE, Borresen-Dale AL, Brown PO and Botstein D. Molecular portraits of human breast tumours. Nature. 2000; 406:74752. | Article | PubMed

10. Sorlie T, Perou CM, Tibshirani R, Aas T, Geisler S, Johnsen H, Hastie T, Eisen MB, van de Rijn M, Jeffrey SS, Thorsen T, Quist H, Matese JC, Brown PO, Botstein D, Lonning PE and Borresen-Dale AL. Gene expression patterns of breast carcinomas distinguish tumor subclasses with clinical implications. Proc Natl Acad Sci U S A. 2001; 98:10869-74. | Article | PubMed Abstract | PubMed Full Text

11. Wesolowski R and Ramaswamy B. Gene expression profiling: changing face of breast cancer classification and management. Gene Expr. 2011; 15:105-15. | PubMed Abstract | PubMed Full Text

12. Comprehensive molecular portraits of human breast tumours. Nature. 2012; 490:61-70. | Article | PubMed Abstract | PubMed Full Text

13. Stephens PJ, Tarpey PS, Davies H, Van Loo P, Greenman C, Wedge DC, Nik-Zainal S, Martin S, Varela I and Bignell GR et al. The landscape of cancer genes and mutational processes in breast cancer. Nature. 2012; 486:400-4. | Article | PubMed Abstract | PubMed Full Text

14. Hollestelle A, Elstrodt F, Nagel JH, Kallemeijn WW and Schutte M. Phosphatidylinositol-3-OH kinase or RAS pathway mutations in human breast cancer cell lines. Mol Cancer Res. 2007; 5:195-201. | Article PubMed

15. Shah SP, Roth A, Goya R, Oloumi A, Ha G, Zhao Y, Turashvili G, Ding J, Tse K, Haffari G, Bashashati A and Prentice LM et al. The clonal and mutational evolution spectrum of primary triple-negative breast cancers. Nature. 2012; 486:395-9. | Article | PubMed Abstract | PubMed Full Text

16. Banerji S, Cibulskis K, Rangel-Escareno C, Brown KK, Carter SL, Frederick AM, Lawrence MS, Sivachenko AY, Sougnez $C$ and Zou L et al. Sequence analysis of mutations and translocations across breast cancer subtypes. Nature. 2012; 486:405-9. | Article | PubMed

17. Tilch E, Seidens T, Cocciardi S, Reid LE, Byrne D, Simpson PT, Vargas AC, Cummings MC, Fox SB, Lakhani SR and Chenevix Trench G. Mutations in EGFR, BRAF and RAS are rare in triple-negative and basal-like breast cancers from Caucasian women. Breast Cancer Res Treat. 2014; 143:38592. | Article | PubMed

18. Kim Y, Kim J, Lee HD, Jeong J, Lee W and Lee KA. Spectrum of EGFR gene copy number changes and KRAS gene mutation status in Korean triple negative breast cancer patients. PLoS One. 2013; 8:e79014. | Article | PubMed Abstract | PubMed Full Text

19. Grob TJ, Heilenkotter U, Geist S, Paluchowski P, Wilke C, Jaenicke F, Quaas A, Wilczak W, Choschzick M, Sauter G and Lebeau A. Rare oncogenic mutations of predictive markers for targeted therapy in triple-negative breast cancer. Breast Cancer Res Treat. 2012; 134:561-7. | Article | PubMed

20. Paranjape T, Heneghan $H$, Lindner R, Keane FK, Hoffman A, Hollestelle A, Dorairaj J, Geyda K, Pelletier C, Nallur S, Martens JW, Hooning MJ, Kerin M, Zelterman D, Zhu Y, Tuck D, Harris L, Miller N, Slack F and Weidhaas J. A 3'-untranslated region KRAS variant and triple-negative breast cancer: a case-control and genetic analysis. Lancet Oncol. 2011; 12:377-86. | Article | PubMed Abstract | PubMed Full Text

21. Pereira CB, Leal MF, de Souza CR, Montenegro RC, Rey JA, Carvalho AA, Assumpcao PP, Khayat AS, Pinto GR, Demachki S, de Arruda Cardoso Smith $M$ and Burbano RR. Prognostic and predictive significance of MYC and KRAS alterations in breast cancer from women treated with neoadjuvant chemotherapy. PLoS One. 2013; 8:e60576. | Article | PubMed Abstract | PubMed Full Text

22. Berns K, Horlings HM, Hennessy BT, Madiredjo M, Hijmans EM, Beelen
K, Linn SC, Gonzalez-Angulo AM, Stemke-Hale K, Hauptmann M, Beijersbergen RL, Mills GB, van de Vijver MJ and Bernards R. A functional genetic approach identifies the PI3K pathway as a major determinant of trastuzumab resistance in breast cancer. Cancer Cell. 2007; 12:395-402. | Article | PubMed

23. Esteva FJ, Guo H, Zhang S, Santa-Maria C, Stone S, Lanchbury JS, Sahin AA, Hortobagyi GN and Yu D. PTEN, PIK3CA, p-AKT, and p-p70S6K status: association with trastuzumab response and survival in patients with HER2-positive metastatic breast cancer. Am J Pathol. 2010; 177:1647-56. | Article | PubMed Abstract | PubMed Full Text

24. Jensen JD, Knoop A, Laenkholm AV, Grauslund M, Jensen MB, SantoniRugiu E, Andersson M and Ewertz M. PIK3CA mutations, PTEN, and pHER2 expression and impact on outcome in HER2-positive earlystage breast cancer patients treated with adjuvant chemotherapy and trastuzumab. Ann Oncol. 2012; 23:2034-42. | Article | PubMed

25. Janku F, Lee JJ, Tsimberidou AM, Hong DS, Naing A, Falchook GS, Fu S, Luthra R, Garrido-Laguna I and Kurzrock R. PIK3CA mutations frequently coexist with RAS and BRAF mutations in patients with advanced cancers. PLoS One. 2011; 6:e22769. | Article | PubMed Abstract | PubMed Full Text

26. Sanchez-Munoz A, Gallego E, de Luque V, Perez-Rivas LG, Vicioso L, Ribelles N, Lozano J and Alba E. Lack of evidence for KRAS oncogenic mutations in triple-negative breast cancer. BMC Cancer. 2010; 10:136. | Article | PubMed Abstract | PubMed Full Text

27. Elston $\mathrm{CW}$ and Ellis IO. Pathological prognostic factors in breast cancer. I. The value of histological grade in breast cancer: experience from a large study with long-term follow-up. Histopathology. 1991; 19:403-10. | Article | PubMed

28. DBCG guidelines, Chapter 3, Pathology. I Pdf

29. Moller S, Jensen MB, Ejlertsen B, Bjerre KD, Larsen M, Hansen HB, Christiansen $P$ and Mouridsen HT. The clinical database and the treatment guidelines of the Danish Breast Cancer Cooperative Group (DBCG); its 30-years experience and future promise. Acta Oncol. 2008; 47:506-24. | Article | PubMed

30. Jarry A, Masson D, Cassagnau E, Parois S, Laboisse $C$ and Denis MG. Realtime allele-specific amplification for sensitive detection of the $B R A F$ mutation V600E. Mol Cell Probes. 2004; 18:349-52. | Article | PubMed

31. Dominguez PL and Kolodney MS. Wild-type blocking polymerase chain reaction for detection of single nucleotide minority mutations from clinical specimens. Oncogene. 2005; 24:6830-4. | Article | PubMed

32. Duffy MJ, O'Donovan $\mathrm{N}$ and Crown J. Use of molecular markers for predicting therapy response in cancer patients. Cancer Treat Rev. 2011 37:151-9. | Article | PubMed

33. Montemurro F, Donadio M, Clavarezza M, Redana S, Jacomuzzi ME, Valabrega G, Danese S, Vietti-Ramus G, Durando A, Venturini M and Aglietta M. Outcome of patients with HER2-positive advanced breast cancer progressing during trastuzumab-based therapy. Oncologist. 2006; 11:318-24. | Article | PubMed

34. Cobleigh MA, Vogel CL, Tripathy D, Robert NJ, Scholl S, Fehrenbacher L, Wolter JM, Paton V, Shak S, Lieberman G and Slamon DJ. Multinational study of the efficacy and safety of humanized anti-HER2 monoclonal antibody in women who have HER2-overexpressing metastatic breast cancer that has progressed after chemotherapy for metastatic disease. $J$ Clin Oncol. 1999; 17:2639-48. | Article | PubMed

35. Romond EH, Perez EA, Bryant J, Suman VJ, Geyer CE, Jr., Davidson NE, Tan-Chiu E, Martino S, Paik S, Kaufman PA and Swain SM et al. Trastuzumab plus adjuvant chemotherapy for operable HER2-positive breast cancer. N Engl J Med. 2005; 353:1673-84. | Article | PubMed

36. Smith I, Procter M, Gelber RD, Guillaume S, Feyereislova A, Dowsett M, Goldhirsch A, Untch M, Mariani G, Baselga J, Kaufmann M, Cameron D, Bell R, Bergh J, Coleman R, Wardley A, Harbeck N, Lopez RI, Mallmann P, Gelmon K, Wilcken N, Wist E, Sanchez Rovira P and Piccart-Gebhart MJ. 2-year follow-up of trastuzumab after adjuvant chemotherapy in HER2positive breast cancer: a randomised controlled trial. Lancet. 2007; 369:29-36. | Article | PubMed

37. Yuan TL and Cantley LC. PI3K pathway alterations in cancer: variations on a theme. Oncogene. 2008; 27:5497-510. | Article | PubMed Abstract 
Jylling et al. Journal of Cancer Therapeutics \& Research 2014,

http://www.hoajonline.com/journals/pdf/2049-7962-3-3.pdf

PubMed Full Text

38. Coughlin CM, Johnston DS, Strahs A, Burczynski ME, Bacus S, Hill J, Feingold JM, Zacharchuk $C$ and Berkenblit A. Approaches and limitations of phosphatidylinositol-3-kinase pathway activation status as a predictive biomarker in the clinical development of targeted therapy. Breast Cancer Res Treat. 2010; 124:1-11. | Article | PubMed

39. Pohlmann PR, Mayer IA and Mernaugh R. Resistance to Trastuzumab in Breast Cancer. Clin Cancer Res. 2009; 15:7479-7491. | Article | PubMed Abstract | PubMed Full Text

40. Razis E, Bobos M, Kotoula V, Eleftheraki AG, Kalofonos HP, Pavlakis K, Papakostas P, Aravantinos G, Rigakos G, Efstratiou I, Petraki K, Bafaloukos D, Kostopoulos I, Pectasides D, Kalogeras KT, Skarlos D and Fountzilas G. Evaluation of the association of PIK3CA mutations and PTEN loss with efficacy of trastuzumab therapy in metastatic breast cancer. Breast Cancer Res Treat. 2011; 128:447-56. | Article | PubMed

41. Kalinsky K, Jacks LM, Heguy A, Patil S, Drobnjak M, Bhanot UK, Hedvat CV, Traina TA, Solit D, Gerald W and Moynahan ME. PIK3CA mutation associates with improved outcome in breast cancer. Clin Cancer Res. 2009; 15:5049-59. | Article | PubMed

42. Barbareschi M, Buttitta F, Felicioni L, Cotrupi S, Barassi F, Del Grammastro M, Ferro A, Dalla Palma P, Galligioni E and Marchetti A. Different prognostic roles of mutations in the helical and kinase domains of the PIK3CA gene in breast carcinomas. Clin Cancer Res. 2007; 13:6064-9. | Article | PubMed

43. Bachman KE, Argani P, Samuels Y, Silliman N, Ptak J, Szabo S, Konishi H, Karakas B, Blair BG, Lin C, Peters BA, Velculescu VE and Park BH. The PIK3CA gene is mutated with high frequency in human breast cancers. Cancer Biol Ther. 2004; 3:772-5. | Article | PubMed

44. Campbell IG, Russell SE, Choong DY, Montgomery KG, Ciavarella ML, Hooi CS, Cristiano BE, Pearson RB and Phillips WA. Mutation of the PIK3CA gene in ovarian and breast cancer. Cancer Res. 2004; 64:7678-81. | Article I PubMed

45. Buttitta F, Felicioni L, Barassi F, Martella C, Paolizzi D, Fresu G, Salvatore S, Cuccurullo F, Mezzetti A, Campani D and Marchetti A. PIK3CA mutation and histological type in breast carcinoma: high frequency of mutations in lobular carcinoma. J Pathol. 2006; 208:350-5. | Article | PubMed

46. Saal LH, Holm K, Maurer M, Memeo L, Su T, Wang X, Yu JS, Malmstrom PO, Mansukhani M, Enoksson J, Hibshoosh H, Borg A and Parsons R. PIK3CA mutations correlate with hormone receptors, node metastasis, and ERBB2, and are mutually exclusive with PTEN loss in human breast carcinoma. Cancer Res. 2005; 65:2554-9. | Article | PubMed

47. Li SY, Rong M, Grieu F and lacopetta B. PIK3CA mutations in breast cancer are associated with poor outcome. Breast Cancer Res Treat. 2006; 96:91-5. | Article | PubMed

48. Perez-Tenorio G, Alkhori L, Olsson B, Waltersson MA, Nordenskjold $B$, Rutqvist LE, Skoog L and Stal O. PIK3CA mutations and PTEN loss correlate with similar prognostic factors and are not mutually exclusive in breast cancer. Clin Cancer Res. 2007; 13:3577-84. | Article | PubMed

49. Dave B, Migliaccio I, Gutierrez MC, Wu MF, Chamness GC, Wong H, Narasanna A, Chakrabarty A, Hilsenbeck SG, Huang J, Rimawi M, Schiff $\mathrm{R}$, Arteaga C, Osborne CK and Chang JC. Loss of phosphatase and tensin homolog or phosphoinositol-3 kinase activation and response to trastuzumab or lapatinib in human epidermal growth factor receptor 2-overexpressing locally advanced breast cancers. J Clin Oncol. 2011; 29:166-73. | Article | PubMed Abstract | PubMed Full Text

50. Wang L, Zhang $Q$, Zhang J, Sun S, Guo H, Jia Z, Wang B, Shao Z, Wang $\mathrm{Z}$ and $\mathrm{Hu} X$. PI3K pathway activation results in low efficacy of both trastuzumab and lapatinib. BMC Cancer. 2011; 11:248. | Article | PubMed Abstract I PubMed Full Text

51. Lai YL, Mau BL, Cheng WH, Chen HM, Chiu HH and Tzen CY. PIK3CA exon 20 mutation is independently associated with a poor prognosis in breast cancer patients. Ann Surg Oncol. 2008; 15:1064-9. | Article | PubMed

52. Ellis MJ, Lin L, Crowder R, Tao Y, Hoog J, Snider J, Davies S, DeSchryver K, Evans DB, Steinseifer J, Bandaru R, Liu W, Gardner H, Semiglazov V, Watson M, Hunt K, Olson J and Baselga J. Phosphatidyl-inositol-3kinase alpha catalytic subunit mutation and response to neoadjuvant endocrine therapy for estrogen receptor positive breast cancer. Breast
Cancer Res Treat. 2010; 119:379-90. | Article | PubMed Abstract | PubMed Full Text

53. Faratian D, Goltsov A, Lebedeva G, Sorokin A, Moodie S, Mullen P, Kay C, Um IH, Langdon S, Goryanin I and Harrison DJ. Systems biology reveals new strategies for personalizing cancer medicine and confirms the role of PTEN in resistance to trastuzumab. Cancer Res. 2009; 69:6713-20. | Article | PubMed

54. Stemke-Hale K, Gonzalez-Angulo AM, Lluch A, Neve RM, Kuo WL, Davies M, Carey M, Hu Z, Guan Y, Sahin A, Symmans WF, Pusztai L, Nolden LK, Horlings H, Berns K, Hung MC, van de Vijver MJ, Valero V, Gray JW, Bernards R, Mills GB and Hennessy BT. An integrative genomic and proteomic analysis of PIK3CA, PTEN, and AKT mutations in breast cancer. Cancer Res. 2008; 68:6084-91. | Article | PubMed Abstract | PubMed Full Text

55. Bussolati G, Montemurro F, Righi L, Donadio M, Aglietta M and Sapino A. A modified Trastuzumab antibody for the immunohistochemical detection of HER-2 overexpression in breast cancer. Br J Cancer. 2005; 92:1261-7. | Article | PubMed Abstract | PubMed Full Text

56. Sapino A, Montemurro F, Marchio C, Viale G, Kulka J, Donadio M, Bottini A, Botti G, dei Tos AP, Bersiga A, Di Palma S, Truini M, Sanna G, Aglietta $\mathrm{M}$ and Bussolati $\mathrm{G}$. Patients with advanced stage breast carcinoma immunoreactive to biotinylated Herceptin are most likely to benefit from trastuzumab-based therapy: an hypothesis-generating study. Ann Oncol. 2007; 18:1963-8. | Article | PubMed

\section{Citation:}

Jylling AMB, Rasmussen AA, Jakobsen EH, Christensen $\mathrm{Rd}$ and Sørensen FB. Are mutations in K-RAS, BRAF and PIK3CA genes critical for response to adjuvant trastuzumab treatment in patients with HER-2 positive breast cancer? J Cancer Ther Res. 2014; 3:3. http://dx.doi.org/10.7243/2049-7962-3-3 